\title{
PENGARUH PEMBELAJARAN VIRTUAL AL-QUR'AN HADITS TERHADAP REVOLUSI MENTAL RELIGIUS PESERTA DIDIK (STUDI KASUS MAN 01 PATI)
}

\author{
Laila Nurul Hidayah* ${ }^{* 1}$, Ashif Az-Zafi*2 \\ IAIN KUDUS \\ Email : ${ }^{1} \underline{11889962 @ g m a i l . c o m},{ }^{2}$ ashifazzafi@iainkudus.ac.id
}

\begin{abstract}
This study aims to identify and produce valid information about the religious mentality of students in the online learning process from home due to the COVID-19 pandemic. In this study, the method and approach used is a case study of the teaching and learning process activities and their effect on the religious mentality of students at MA Negeri 01 Pati. The results obtained are various problems faced by students in conducting online learning from home, including the lack of mastery of modern technology, additional spending to buy internet quota, reduced interaction between students. This is very influential on the religious mentality of students, among others, their prayers are not on time (procrastination), their prayers are incomplete 5 times, rarely carry out their sunnah prayers and reading the Qur'an are reduced, as well as their social attitudes are not good. Because usually there are teachers who directly provide examples, guide and remind them.
\end{abstract}

Keywords: Mental Character, Learning From Home, Covid-19 Pandemic

\begin{abstract}
Abstrak
Penelitian ini mempunyai untuk mengidentifikasi dan menghasilkan informasi yang valid tentang mental religius siswa dalam proses pembelajaran online dari rumah yang disebabkan adanya pandemi COVID-19. Pada penelitian ini metode dan pendekatan yang digunakan yaitu studi kasus terhadap kegiatan proses belajar mengajar serta pengaruhnya terhadap mental religius siswa di MA Negeri
\end{abstract}

\footnotetext{
* Fakultas Ilmu Tarbiyah dan Keguruan Universitas Islam Negeri Sunan Kaliaga, Jl. Laksda Adisucipto Yogyakarta 55281, Daerah Istimewa Yogyakarta Tepl: (0274) 519709

* Fakultas Ilmu Tarbiyah dan Keguruan Universitas Islam Negeri Sunan Kaliaga, Jl. Laksda Adisucipto Yogyakarta 55281, Daerah Istimewa Yogyakarta Tepl: (0274) 519709
} 
01 Pati. Hasil penelitian yang diperoleh adalah berbagai permasalahan yang dihadapi siswa dalam melakukan pembelajaran online dari rumah antara lain penguasaan teknologi modern yang masih kurang, adanya tambahan pengeluaran untuk beli kuota internet, berkurangnya interaksi antar siswa. Hal tersebut sangatlah berpengaruh terhadap mental religius siswa antara lain sholatnya tidak tepat waktu (menunda-nunda), sholatnya tidak lengkap 5 waktu,, jarang melaksanakan sholat sunnahnya dan membaca Al-Qur'annya menjadi berkurang, begitu juga sikap sosialnya kurang baik. Karena yang biasanya ada guru yang secara langsung memberikan contoh, membimbing dan mengingatkan mereka.

Kata Kunci: Mental Religius, Belajar Dari Rumah, Pandemi Covid-19

\section{Introduction}

learning is a teaching and learning activity that involves a person to acquire knowledge, skills and positive values by utilizing various sources for learning. In learning, it involves two parties, namely students as students and teachers as teachers. The occurrence of the learning process is the most important thing in the learning process. (Rohani, 2019)

In the Ministry of Education and Culture's KBBI, online is an acronym for the network. This means that it is connected via computer networks, the internet and so on. (KKBI) Online is the Indonesian language from online. The network can also be interpreted as a computer that exchanges information because it is connected to an internet. This concept has been extended from the meaning of computing and telecommunication to the field of human interaction and conversation (Abdi 2020).

Online is a collection of hardware combined, used to create simulations about the environment. The environment that is created is a replica of the real environment with three-dimensional settings, images and sounds (M.Bashoirul W Sinambela, Yerry Soepriyanto 2020).

Online learning is an educational reform that involves an element of information technology in the learning process. Online learning is a distance education system with a set of teaching methods where there are teaching activities that are carried out separately from learning activities. Online learning is held through the internet network, which means that the use of online learning involves elements of technology 
as a means and the internet network as a system. (Yani Fitriyani, Irfan Fauzi 2020).

It can be concluded that virtual learning is a learning process carried out with internet access. By implementing virtual learning students can learn on their own through computer assistance or interactive web pages.

Mental Revolution contains three stages that are simple and young for everyone to understand, namely "first, the awareness of the various problems that occurred in our life and the hope for a better future; second, the turning point process that denies or rejects all badacts and inhumane ways of life; third, let God be the center of life so that our life becomes more humane ". Mental revolution is not only about mindset but more than that. Interpreting 'mental' as the name for everything that concerns the way of life, the way of thinking, the way of looking at problems, the way of feeling, the way to believe / believe, how to behave and act. (Lailiyatur Romadhoni, Diloda Shokhibul Anam, Maya Lestari, 2020) Character and culture have a very close relationship with mental. When mental is interpreted so broadly, mental revolution must dismantle a culture that has been deeply ingrained and now part of it has been lost. One of them is a culture of shame (Kristiawan 2015).

There is a policy to carry out all activities at home. The Ministry of Education and Culture stipulates the implementation of online learning which aims to prevent the spread of covid-19. With the enactment of these regulations, all learning activities are carried out online, including from elementary schools to tertiary institutions. This forces the school to change the face to face learning system into online learning (Funsu Andirana 2020). Online learning is a learning activity that uses the internet network as a method of interacting between students and teachers in learning, such as delivering material that can be done with computer facilities, laptops or smartphones connected to the internet network. With these facilities, lecturers and students can study together at the same time using platforms such as WhatsApp, telegram, zoom, meet, google classroom (Fitriah n.d.)

Initially online learning received a positive response from some students, however, as time went on the learning process, students experienced many difficulties. Among other things, namely the difficulty of the signal, some students have limited quotas, interference 
when carrying out learning activities at home, students do not focus on learning without direct interaction with teachers or other students, difficulty understanding the material that has been delivered, teachers are not maximal in preparing material (Gunadha 2020). The obstacle that is very burdensome for students is when there are many tasks with short deadlines.

The word "mental health" is taken from the concept of mental hygiene. The word "mental" is taken from Greek, the meaning is the same as psyche in Latin which means psychic, soul or psychiatric. So the term mental hygiene is defined as mental health or mental health. The theory of psychoanalysis of mental-unconsciousness is a driving force for behavior pioneered by Sigmund Freud.

Learning online is a learning activity that is carried out without face-to-face contact between teachers and students, but online. Various aspects of learning online, namely in the learning process using media as a communication tool, the teacher must be ready and master the material to be delivered, both test and non-test assignments are given to students to evaluate learning outcomes, then at each meeting students are trained to be independent in develop his knowledge.

In the world of education, the use of e-learning technology or online learning will change the view of the teaching and learning process. Teachers get a more dominant position in the teacher-oriented process. And the students emphasize the independent learning process in a student-oriented learning system. One of the main supporters of the learning system is the teacher, which in the end, students can actively learn to use the various facilities available in the available information sources (Budi 2017).

From the above explanation, this study aims to determine the effect of virtual learning of the Al-Qur'an Hadith on the religious mental revolution of students during the Covid-19 pandemic. Because the religious mentality of students is very important in learning activities, this research must be carried out. The influence of the disruption of learning outcomes that is not optimal, it is necessary information related to further action learning in the network.

research method uses qualitative research methods with in-depth analysis. In this study, two types of data were used, namely primary data and secondary data. Primary data comes from the first source of results from online interviews. Meanwhile, secondary data is obtained 
from reliable sources such as articles, books, and websites related to the research. The selected respondents were MAN 01 PATI students who were doing school online during the COVID-19 pandemic. The data collection technique in this research is structured interviews to MAN 01 PATI students who carry out learning in the network. Online interviews were conducted by giving several questions in the form of documents sent via personal message to each student who would be sampled. Closed questionnaires were carried out by distributing via WhatsApp groups and private messages.

\section{Discussion}

\section{The meaning of the Al-Qur'anhadith}

Educationcomes from the word "educate" by giving it the prefix "pe" and the suffix "an", embodies the meaning of "action" (thing, method or so). The term education originally came from the Greek word "pedagogie", which means guidance given to children. This term was later translated into English as "education" which means development or guidance. In Arabic the meaning of education is often used several terms including: al-ta'im, al-tarbiyah and al-ta'dib which means teaching that is giving or delivering knowledge or skills. Altarbiyah means to educate and al-ta'dib is more inclined to the educational process which leads to perfecting the morals of students. However, the word education is more often translated as "al-tarbiyah" which means education (Suriansyah 2011).

One of the important things in human life is education. One of the factors to increase Indonesia's human resources in order to create a quality successor to the nation and to be able to compete with other countries in the world is education. The Indonesian government with its 12-year compulsory education program (Law No. 20 on the 2003 National Education System) is one of the efforts to create the nation's future generation, even now the government has provided free education facilities up to high school level so that all Indonesians can enjoy it. education. As we know that pursuing knowledge is obligatory and Allah will elevate the level of knowledgeable people according to the word of Allah in QS Al Mujadalah: 11 which means: "O people who believe when it is said to you," Give spaciousness in assemblies. assemblies, "then make it clear, surely Allah will provide space for you. And when it is said," Stand ye, "then stand up, surely Allah will raise the rank of those who 
believe among you and those who are given the degree of knowledge. Examine what you are doing.

One of the supporting subjects for character education is the lesson of Islamic Religious Education. Islamic Religious Education is an integral part of religious education which includes aspects of AlQur'an hadith, Aqidah Akhlak, worship practices, Fiqh and Date. This form of modeling can change the behavior of students In everyday life students are able to practice sho worship lat, wudu ', make dzikir and pray well, or be able to read the Koran correctly in accordance with the makhraj and recitation (Jamil 2021).

The Qur'an comes from the word Al-Qarain ajamak from the word qarinah which means indicator or hint. Al-Qur'an is the word of Allah SWT which was written to the Prophet Muhammad through the angel Gabriel written in the Mushaf and arrived at us mut Worried or continuously which functions as a guide for human life who reads it is worship starting with the letter al-Fatihah and ending with the An-Nas letter. Meanwhile, according to language, Hadith means alJadid (something new), the opposite of al-Qadim (something old). The word Hadith also means Khabar (news), which is something that is discussed from one person to another (Ampel 2021).

So the Koran itself is the holy book of Muslims used by humans as a guide for life in everyday life. Meanwhile, hadith is a reinforcement of the Koran, which creates shari'ah (tasyri ') laws that have not been explained by the Koran. Islamic religious education has several elements of subjects, one of which is the subject of al-qur'an hadith. By understanding the Koran and hadith, students will understand the source of the teachings of the Islamic Religion and be able to practice the contents of their views as guidance and a foundation in everyday life.

Learning al-qur'an and hadith is carried out with the aim of developing students' knowledge of al-qur'an and hadith, so that they get good and correct knowledge of both. Learning the Koran and hadith at Madrasah Aliyah emphasizes the abilities that a Muslim must have. Among them are reading, writing, memorizing, interpreting, understanding and practicing the Koran and hadith in everyday life.

A teacher must be able to read the Koran correctly and understand the meaning of the contents of the Koran. In addition, of course, you 
have to prepare learning approaches that will be used in delivering the material. And, a good teacher is also required to prepare learning resources and learning media properly in order to achieve the learning objectives that will be conveyed.

\section{Religion as Therapy for Psychiatric Disorders}

In treating the soul religion has a very important role. The application of religion in daily life can fortify a person from mental disorders and can restore mental health to people who are anxious because of anxiety, that endless anxiety, which generally comes from dissatisfaction, while religion can help people to accept temporary disappointments by by way of asking for the pleasure of Allah SWT.

Praying, praying and asking forgiveness from Allah SWT, are methods of inner relief that will restore peace and tranquility of the soul to those who do it.

The closer people are to their God and the more prayer and worship, the more peaceful their souls will be and able to face disappointments in their lives (Pujianti 2018)

Thus, the function of religion in life is to provide guidance in life to humans, be it children, adults or the elderly. Helping religion in adversity, if it is abundant, such as the problem of disappointment that humans experience for people of religion, any difficulty or danger, they will be sane and patient in dealing with these problems. Religion calms the mind of a religious person. He will feel peace in his soul and mind if he draws closer to God Almighty.

\section{The Effect of Online Learning on the Religious Mental of Students}

In the Covid 19 pandemic situation which requires students to learn at home using the online method, it requires students or parents to always be ready with their Android phones because most teachers send teaching materials and assignments via WhatsApp Messenger group, zoom, goegle meet and other learning applications, which are then collected via WhatsApp Messenger, zoom, goegle meet and other learning applications. Parents have a very important role in this online learning method, especially teaching materials that are only sent in the form of PowerPoint, Microsoft Word, or in the form of pictures which then students in parental assistance are required to understand by themselves. The conditions of different parents make the output produced by each student also different, but students are required to 
understand as when doing school normally. During online learning, most teachers do not evaluate the material that has been delivered to their students, which results in many students who do not understand the material presented. It is also very influential on the mental development of students.

Mental health is important, mental health is one of the health supports, so mental health cannot be ignored. Several factors can affect the mental health of students, including: genetic factors, family factors, friendship factors, lifestyle factors, social factors, environmental factors and various other factors. These factors can affect students both positively and negatively (Uswatun Hasanah, Ludian, Immawati 2020).

The application of online learning is the prevention of the spread of covid-19. Online learning has a negative mental impact on students, including the following:

a. Reduced effectiveness of teaching and learning activities

b. Obstruction of social interaction with other people

c. Slowness of development

d. Have a high sense of worry

e. The body's immunity is getting weaker (Mahmudah 2020).

f. students do not use social media to not study and read material from the teacher, but use it for other things

g. Lack of students' intention to learn so that it has an impact on learning that is poorly understood

h. It is possible that there are many loopholes in the application system that result in crime and fraud

i. Tasks are piling up more

j. The learning activities are not effective to-face learning because learning is not effective number of learners who do not understand and the lack of explanation from the teacher

Besides the negative impact of the implementation of online learning has positive impacts such as:

a. Students have a lot of free time with family

b. More flexible, because there are many methods that can be applied while studying at home

c. Like it or not, students must learn technology 
d. There are students who feel comfortable studying at home because it is not noisy

e. Get material easily and be able to evaluate learning at home according to our wishes

f. Can study well in a closed or open room without knowing the time limit that is usually set during learning in school during the course of the event

g. Can do online learning casually

h. To break the chain of virus spread and be safe from the dangers of the corona virus teaching and learning activities are carried out online (Nur Fadhila Andini 2020).

It can be concluded that the positive effect of online learning is that students can obtain material quickly and easily and can access material anytime and anywhere in a relaxed and safe manner from the dangers of the corona virus. Meanwhile, the negative impact of online learning for students is the lack of interest in learning for students and the accumulation of tasks and constraints on the network.

This application affects the mentality of students, for example obstacles in the process of achieving learning, so that achievement decreases. Learning the mind should develop not even degenerate. Therefore, students must get support to restore a good and effective mental.

From the results of interviews with students of MAN 01 PATI, the effect of online learning greatly affects the mental condition of students, including the threat of dropping out of school to help parents earn a living because there is no money to buy data packages, they are more tempted by online games, causing a decrease in student learning achievement. , being an outlet for parents, the lack of socializing with others makes students have a pessimistic attitude, easy going down and so on.

\section{Conclusion}

Based on the results of the analysis and discussion of this study, it can be concluded that students feel positive and negative impacts during the implementation of online learning. However, there are not a few negative impacts that are only felt by students during online learning. It is the negative impact that results from online learning that 
can attack the mentally of students. If a student only thinks about the negative impact of online learning, then the student will become stressed and can cause students to have mental problems. Therefore, students must try to stay mentally healthy by making some efforts which they think are able to reduce stress.

Due to this negative impact, it is better if the school or education party can provide for each student when online learning takes place. For example, by not giving too many assignments, providing material in an interesting and not boring manner, and understanding if students accidentally come out of zoom meating, goeglee meet and so on because of network problems. With these things students can relieve a little sense of stress because the load is slightly reduced.

\section{References}

Abdi, Husnul. 2020. “Arti Daring Dan Luring Dalam Pembelajaran Kenali Jenisnya."

Ampel, Tim Penyususn MKD IAIN Sunan. 2021. Studi Al-Qur'an. Surabaya: IAIN Sunan Ampel.

Budi, Eko Nur. 2017. “Penerapan Pembelajaran Virtual Class Pada Materi Teks Eksplanasi Untuk Meningkatkan Aktivitas Dan Hasil Belajar Bahasa Indonesia Siswa Kelas XI IPS 2 SMA 1 Kudus." Jurnal Pendidikan Ilmu Sosial 27(2).

Fitriah. n.d. “Dampak Pembelajaran Daring Bagi Mahasiswa Masa Pandemi Covid 19."

Funsu Andirana, Estri Kusumawati. 2020. “Pengaruh Pembelajaran Daring Terhadap Ses Akademik Mahasiswa Selama Pandemi Covid 19." Jurnal Psikologi 6(2).

Gunadha, Rahmayunita. 2020. “Kuliah Online Saat Corona Picu Ketimpangan Akses Bagi Mahasiswa Miskin." 
Jamil. 2021. "Peranan Pembelajaran Modeling Dalam Meningkatkan Ketrampilan Beribadah Siswa Di Madrasah Aliyah Negeri 3 Medan." Jurnal Ansiru 1(1).

Kristiawan, Muhammad. 2015. “Telaah Revolusi Mental Pendidikan Karakter Dalam Pembentukan Sumber Daya Manusia Yang Pandai Dan Berakhlak Mulia." Jurna Ta'dib 18(1).

M.Bashoirul W Sinambela, Yerry Soepriyanto, Eka Pramono Adi. 2020. “Taman Peninggalan Sejarah Berbasis Virtual Reality." JKTP $1(1)$.

Mahmudah, Safira Rona. 2020. "Pengaruh Pembelajaran Daring Terhadap Psikologis Siswa Terdampak Social Distancing Akibat Covid 19." Jurnal Al-Mau'izhoh 2(2).

Nur Fadhila Andini. 2020. “Dampak Pembelajaran Daring Bagi Mahasiswa Masa Pandemi Covid 19."

Pujianti, Yatim. 2018. “Fungsi Agama Terhadap Kesehatan Mental Menurut Zakiah."

Suriansyah, Ahmad. 2011. Landasan Pendidikan. Banjarmasin: Comdes.

Uswatun Hasanah, Ludian, Immawati, luviana PH. 2020. “GambaranPsikologis Mahasiswa Dalam Proses Pembelajaran Selama Pandemi Covid 19." Jurnal Keperawatan Jiwa 8(3).

Yani Fitriyani, Irfan Fauzi, Mia Zyltriani Sari. 2020. “Motivasi Belajar Mahasiswa Pada Pembelajaran Daring Selama Pandemik Covid 19." Jurnal Kependidikan 6(2). 